\title{
Human amniotic membrane as an alternative source of stem cells for regenerative medicine
}

\author{
Silvia Díaz-Prado, Emma Muiños-López, Tamara Hermida-Gómez, Claudia Cicione, c, \\ M. Esther Rendal-Vázquez, Isaac Fuentes-Boquete, b, Francisco J. de Toro, Francisco J. \\ Blanco
}

\begin{abstract}
The human amniotic membrane (HAM) is a highly abundant and readily available tissue. This amniotic tissue has considerable advantageous characteristics to be considered as an attractive material in the field of regenerative medicine. It has low immunogenicity, anti-inflammatory properties and their cells can be isolated without the sacrifice of human embryos. Since it is discarded post-partum it may be useful for regenerative medicine and cell therapy. Amniotic membranes have already been used extensively as biologic dressings in ophthalmic, abdominal and plastic surgery. HAM contains two cell types, from different embryological origins, which display some characteristic properties of stem cells. Human amnion epithelial cells (hAECs) are derived from the embryonic ectoderm, while human amnion mesenchymal stromal cells (hAMSCs) are derived from the embryonic mesoderm. Both populations have similar immunophenotype and multipotential for in vitro differentiation into the major mesodermal lineages, however they differ in cell yield. Therefore, HAM has been proposed as a good candidate to be used in cell therapy or regenerative medicine to treat damaged or diseased tissues.
\end{abstract}

Keywords

Amniotic membrane; Mesenchymal stem cell; Cartilage; Osteoarthritis; Differentiation pluripotent; Amnion-derived cells

\section{Mesenchymal stem cell therapy as a new clinical approach to treat osteoarthritis}

Osteoarthritis (OA) is a degenerative joint disease characterized by deterioration in the integrity of hyaline cartilage and subchondral bone (Ishiguro et al., 2002). OA is the most common articular pathology and the most frequent cause of disability. Genetic, metabolic and physical factors interact in the pathogenesis of OA producing cartilage damage. The incidence of OA is directly related to age and is expected to increase along with the median age of the population (Brooks, 2002).

The prevalence of OA in the human population underscores the importance of developing an effective and functional articular cartilage replacement. Recent research efforts have focused on tissue engineering as a promising approach for cartilage regeneration and repair (Kuo et al., 2006). Cartilage tissue engineering is critically dependent on the selection of appropriate cells, suitable scaffolds for cell delivery and biological stimulation with chondrogenically bioactive molecules (Kuo et al., 2006).

Articular cartilage receives its nourishment through diffusion from the synovial fluid. The capacity for the self-repair of articular cartilage is very limited, mainly because it is an avascular tissue (Steinert et al., 2007, Mankin, 1982, Resinger et al., 2004 and Fuentes-Boquete et al., 2008). Consequently, progenitor cells in blood and marrow cannot enter the damaged region to influence or contribute to the reparative process (Steinert et al., 2007).

There are a lack of reliable techniques and methods to stimulate growth of new tissue to treat degenerative diseases and trauma (Wong et al., 2005). Currently, there are no effective pharmaceutical treatments for OA, although some medications slow its progression (Brandt and Mazzuca, 2006 and Steinert et al., 2007). There are also no surgical approaches to treat OA; however, surgery is an important tool for the repair of cartilage injuries, which if left untreated may result in secondary OA.

To date, most efforts made to repair an articular cartilage injury are intended to overcome the limitations of this tissue for healing by introducing new cells with chondrogenic capacity (Koga et al., 2008) and facilitating access to the vascular system. Of the numerous treatments available nowadays, no technique has yet been able to consistently regenerate normal hyaline cartilage. Current treatments generate a fibrocartilaginous tissue that is different from hyaline articular cartilage. To avoid the need for 
prosthetic replacement, different cell treatments have been developed with the aim of forming a repair tissue with structural, biochemical and functional characteristics equivalent to those of natural articular cartilage. The overall objective is not only to heal the chondral defect (repair), but to generate new tissue identical to native articular cartilage in structure, biochemical composition and functional behavior (regeneration) (Fuentes-Boquete et al., 2007).

Cell therapy is a new clinical approach for the repair of damaged tissues. Cell therapy using MSCs (Koga et al., 2008) or differentiated chondrocytes (autologous chondrocyte implantation, ACI) is one therapeutic option for the repair of focal lesions of articular cartilage, which is most successful in young people producing repair tissue of high quality (Brittberg et al., 1994 and Minas and Chiu, 2000).

MSCs are multipotent non-hematopoietic progenitors located within the stroma of the bone marrow and other organs that are phenotypically characterized by the expression of several markers (e.g., CD73, CD90 and CD105) and the lack of expression of CD14 or CD11b, CD19 or CD79 $\alpha$, CD34, CD45 and HLA-DR surface molecules (Mrugala et al., 2009 and Kastrinaki et al., 2008). Moreover, characteristics of MSCs are also the expression of surface markers like Stro-1, CD44, CD73, CD90, CD105 and CD166 (Pittenger et al., 1999). According to a recent proposal of the International Society for Cellular Therapy (Dominici et al., 2006) there are three criteria to define all types of stem cells: self-renewal, multipotency and the ability to reconstitute a tissue in vivo. Because there is no specific marker for MSCs, the principal criteria for identification are fibroblast-like morphology, adherence to the plastic of the tissue culture flask ( Prockop, 1997), the prolonged capacity for proliferation and the potential to differentiate in vitro into cells of mesodermal lineage.

MSCs can be isolated by adherence to plastic, expanded ex vivo and induced, both in vitro or in vivo, to terminally differentiate into ectodermal (e.g., neurons) and endodermal (e.g., hepatocytes) lineages ( Pasquinelli et al., 2007) and also into cell of mesodermal origin (e.g., osteocytes, chondrocytes, adipocytes, tenocytes, myotubes, astrocytes and hematopoietic-supporting stroma) ( Barlow et al., 2008, Minguell et al., 2000 and Caplan, 1991). MSCs derived from bone marrow show a higher potential for osteogenic differentiation ( Muraglia et al., 2000), while MSCs of synovial origin show a greater tendency toward chondrogenic differentiation ( Djouad et al., 2005). Under identical culture conditions for differentiation, MSCs isolated from the synovial membrane show more chondrogenic potential than those derived from bone marrow, periostium, skeletal muscle or adipose tissue ( Sakaguchi et al., 2005). These results indicated that MSCs from different tissue sources can have biologic distinctions. Studies of cartilage injury repair in animal models using MSCs embedded in collagen gel ( Wakitani et al., 1989) or injected into defects closed with periosteal membrane ( Im et al., 2001) indicate that MSCs can differentiate in vivo into a number of cell types in different biologic environments.

The recent use of autologous or allogenic stem cells has been suggested as an alternative therapeutic approach for treatment of cartilage defects (Jung et al., 2009). MSCs have the capability to self-renew and are responsible for repair and repopulation of damaged tissues in the adult (Hombach-Klonisch et al., 2008, Pittenger, 2008 and Tsai et al., 2007). The use of autologous MSCs represents the advantage of avoiding the problem of immunological rejection of the allotransplant and the ethical conflict of using human embryonic stem cells (hESCs). Due to the low number of MSCs that can be isolated from a tissue biopsy, proliferation in vitro is necessary to obtain adequate cell numbers for their implant into the patient. Nevertheless, the number of mitotic divisions of MSCs in culture must be limited because MSCs age during in vitro culture, causing a reduction in their proliferative and multi-differentiation potential (Banfi et al., 2000, Bonab et al., 2006 and Izadpanah et al., 2006). The conservation of phenotype and differentiation capacity of MSCs is proportional to telomerization (Abdallah et al., 2005). Telomeres are normally shortened in successive cell divisions, however, in embryonic stem cells the telomere length is restored by telomerase enzyme activity. On the other hand, MSCs lack (Zimmermann et al., 2003) adequate levels of telomerase activity to achieve telomeric restoration (Izadpanah et al., 2006, Parsch et al., 2004 and Yanada et al., 2006). Patient age also influences the characteristics of MSCs because their proliferative capacity is reduced by aging (Stenderup et al., 2003).

Human MSCs have been isolated from several tissues such as bone marrow (Kastrinaki et al., 2008 and Yoo et al., 1998), articular cartilage (Alsalameh et al., 2004), synovial membrane (De Bari et al., 2001 and Fickert et al., 2003), perichondrium (Dounchis et al., 1997), periostium (Nakahara et al., 1990), connective tissue of dermis and skeletal muscle (Young et al., 2001), adipose tissue (Zuk et al., 2001 and Zuk et al., 2002), peripheral blood (Villaron et al., 2004, Kuznetsov et al., 2001 and Zvaifler et al., 2000), liver (Le Blanc et al., 2005), lung (In’tAnker et al., 2003), placenta (Barlow et al., 2008, Steigman and Fauza, 2007 and Fauza, 2004: Matikainen and Laine, 2005), umbilical cord (Baksh et al., 2007, McGuckin et al., 2005 and Samuel et al., 2008), umbilical cord blood (Mareschi et al., 2001), amniotic fluid (You et al., 2008, Steigman and Fauza, 2007 and Fauza, 2004) and amniotic membrane (Díaz-Prado et al., 2010a, Díaz-Prado et al., 2010b and Alviano et al., 2007). Moreover, the list of tissues 
with the potential for tissue engineering is increasing because of recent progress in stem cell biology (Bianco and Robey, 2001).

Although bone marrow is the traditionally used tissue source of adult MSCs, it has some limitations. Among the most important limitations are accessibility and that the procedure required to obtain this kind of tissue is invasive, painful and possibility of donor site morbidity, that the number of MSCs obtained is low, and that the potential to proliferate and differentiate diminishes as the donor's age increases (Soncini et al., 2007, Baksh et al., 2007, Wei et al., 2009 and Ilancheran et al., 2009). The identification of alternative sources of MSCs would be beneficial for both research and therapeutic purposes.

\section{Structure of human amniotic membrane}

HAM develops from extra-embryonic tissue and consists of a fetal component, the chorionic plate and a maternal component, the deciduas, which are comprised of an epithelial monolayer, a thick basement membrane and an avascular stroma (Niknejad et al., 2008 and Jin et al., 2007). The amnion (Fig. 1) is a thin (up to $2 \mathrm{~mm}$ ), elastic, translucent and semi-permeable fetal membrane attached to the chorionic membrane. Both the amnion and chorion form the amniotic sac filled with amniotic fluid, providing and protecting the fetal environment. The outer layer, the chorion, consists of trophoblastic chorionic and mesenchymal tissues. The inner layer, the amnion, consists of a single layer of ectodermally derived epithelium uniformly arranged on the basement membrane, which is one of the thickest membranes found in any human tissue, and a collagen-rich mesenchymal layer (Wilshaw et al., 2006). This mesenchymal layer can be subdivided into the compact layer forming the main fibrous skeleton of the HAM, the fibroblast layer and an intermediate layer, which is also called the spongy layer or zona spongiosa ( Niknejad, et al. 2008).

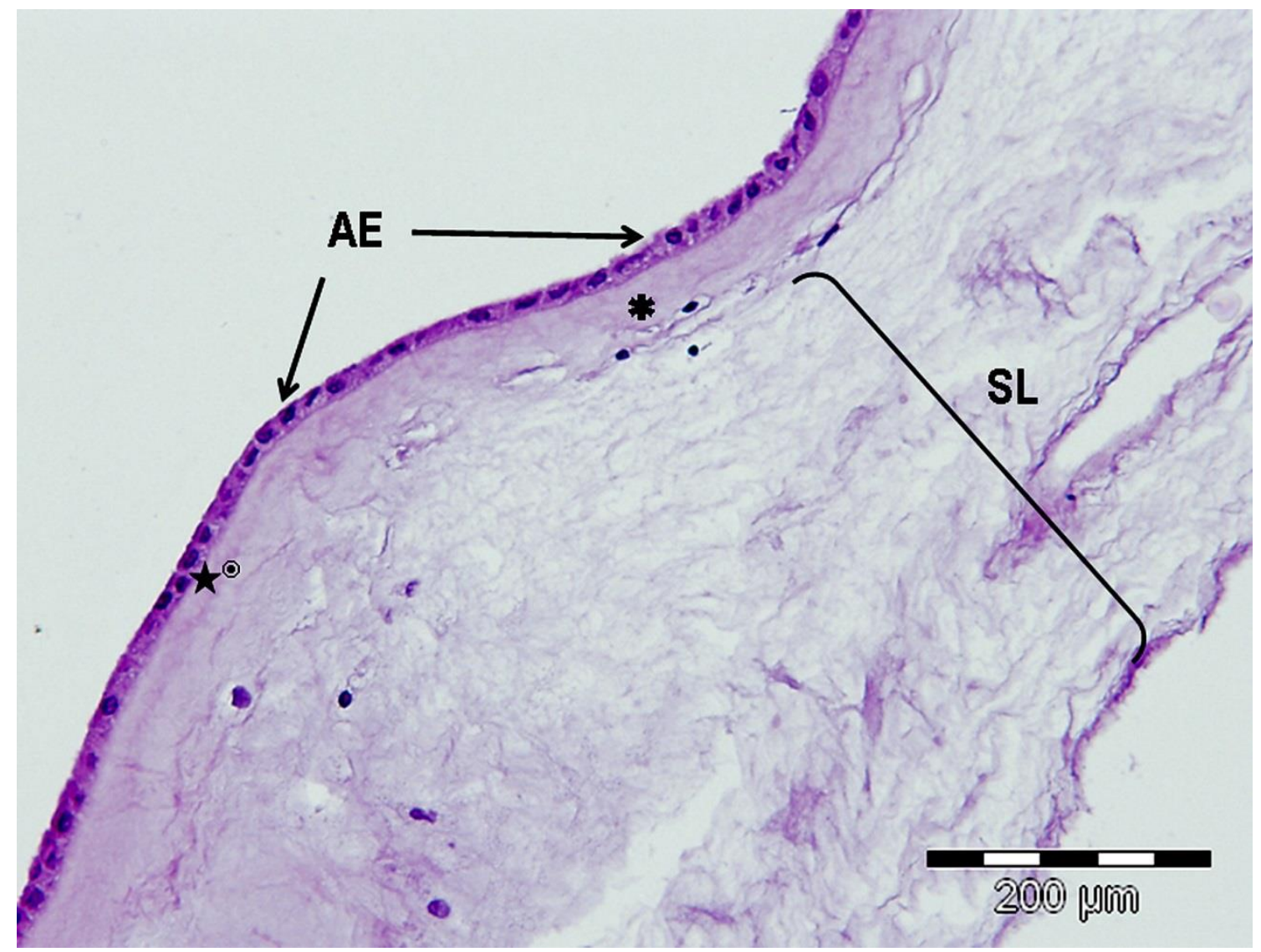

Fig. 1. Structure of the HAM. HAM was stained with HE, hematoxylin and eosin. AE: Amniotic epithelium; $\star$ : Basement membrane; $\odot$ : Compact layer; $/$ : Fibroblastic layer and SL: Spongy Layer or zona spongiosa. 


\section{Potential applications of human amniotic membrane}

Recent studies have focused on tissue engineering as a promising approach for cartilage regeneration (Kuo et al., 2006). Cartilage tissue engineering is based on the selection of appropriate cells, suitable scaffolds and stimulation with chondrogenic molecules (Kuo et al., 2006). Both natural and synthetic polymers have been fabricated for cartilage tissue engineering, such as fibrous structures, porous sponges, woven or non-woven meshes and hydrogels (Tritz et al., 2010, Yuan et al., 2010 and Kuo et al., 2006).

In cartilage tissue engineering, recent studies have focused not only on appropriate cells but also on novel methods of manufacture allowing building stratified scaffolds. In this regard, Han et al. (2008) established and validated a molding technique for fabrication of cartilaginous constructs that are anatomically shaped on one or two surfaces, targeting the spherically shaped hip and biomimetically stratified with superficial and middle/deep zone chondrocyte subpopulations. On the other hand, Tritz et al. (2010) aimed to buildup complex biomaterials for reconstructing biological tissue with three dimensional cells construction for mimicking cartilage architecture. These authors published for the first time that is possible to spray mixed alginate and chondrocytes with little damage for cells. Therefore, the sprayed hydrogel keeps not only the mechanical properties needed for cells, but also maintains the chondrocyte phenotype to induce cartilage.

HAM has some characteristics that highlight their clinical use as scaffold compared to other biocompatible products. In this regard HAM is anti-microbial, anti-tumorigenic, anti-fibrosis, antiangiogenic and has acceptable mechanical properties. It also reduces pain and inflammation, inhibits scarring, shows little or no immunogenicity thus it does not represent transplantation risks, enhances wound healing and epithelialization and acts as an anatomical and vapor barrier (Dua et al., 2004, Ganatra, 2003, Gomes et al., 2005 and Hao et al., 2000). In vitro studies have demonstrated that cells isolated from amnion do not trigger immuno allogenic or xenogenic responses, actively suppress the proliferation of $\mathrm{T}$ lymphocytes and inhibit the differentiation of monocytes. The HAM survives for long periods in immunocompetent animals and the cells are grafted persistently in various organs and tissues. Amnion expresses the non-classic and little polymorphic HLA-G molecules (class I b) and lacks the highly polymorphic antigens HLA A-B-C- (class I a), HLA DR (class II) and the T cell co-stimulatory molecule B-7. The HLA-G molecule displays at least four inhibitory functions relevant to immune responses (Insausti et al., 2010): (a) it can bind directly to inhibitory receptors found in NK cells and other leukocytes. (b) It possesses the appropriate leader peptide for binding to HLA-e, which will in turn inhibit the NK cells via their CD94/NKg2 receptor. (c) It can induce apoptosis of activated CD8+ T cell. (d) It can inhibit CD4+ T cell proliferation. Moreover, in mixed lymphocyte reactions using allogeneic cells, hAECs and hAMSCs, do not induce a cytotoxic response and inhibits lymphocyte proliferation (Ilancheran et al., 2009).

These properties enable surgeons to apply the HAM graft on various tissue surfaces without suturing. HAMs have been used as biologic dressings for ophthalmology, plastic surgery, dermatology and gynecology procedures (Tejwani et al., 2007, Santos et al., 2005, Harijadi et al., 2006, Meller et al., 2000 and Morton and Dewhurst, 1986). Moreover, the extracellular matrix (ECM) of the HAM has several components such as laminin, different types of collagens (I, III, IV, V and VI), nidogen, fibronectin, growth factors, hyaluronan and proteoglycans (Niknejad et al., 2008, Harijadi et al., 2006 and Jin et al., 2007) that are abundant on natural cartilage and are responsible of regulation and maintenance of normal chondrocyte metabolism (Jin et al., 2007); suggesting their use for cartilage tissue engineering (Niknejad et al., 2008). Indeed, a recent report showed the utility of the HAM as a scaffold to support human chondrocyte proliferation in cell therapy to repair human OA cartilage (Díaz-Prado et al., 2010c) (Fig. 2). The low cost of HAM graft preparation and the very good clinical results in different applications have proposed the amnion as an alternative to other natural and synthetic wound dressings. 

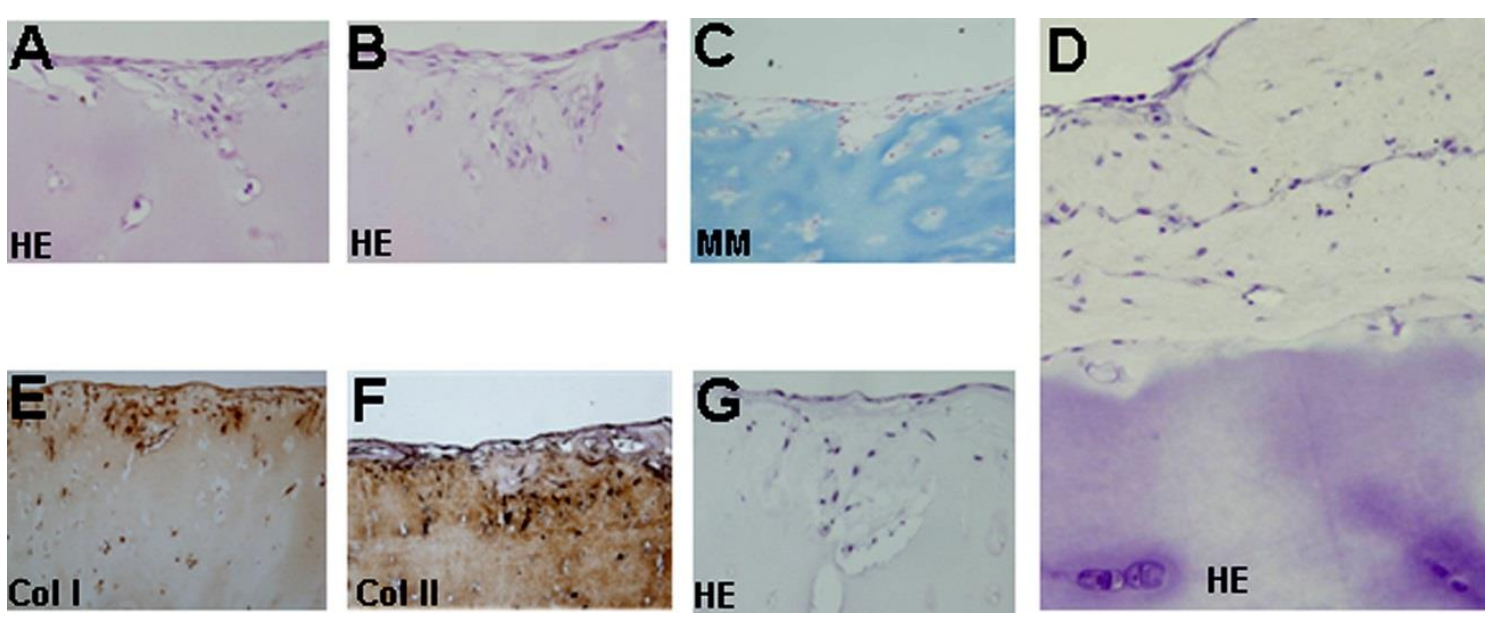

Fig. 2. In vitro repair model of human $\mathrm{OA}$ articular cartilage. Human articular chondrocytes grown over HAM provided a superficial cell cover that decreased the degree of damages of the OA articular cartilage surface (A, B, C and G). The newly-formed tissue showed high cell density and a thickening of the basement membrane of the HAM (D). Type I (E) and type II (F) collagen immunostainings indicated the fibrocartilaginous nature of the newly synthesized tissue. HE, hematoxylin and eosin; MM, Masson's trichrome; Col I, type I collagen; Col II, type II collagen. Original magnifications: (A), (B) and (D) 200x; (C), (E), (F) and (G) $100 \times$.

Published data suggest that HAM is a very attractive source of MSCs. Since the amniotic membrane arises from embryonic epiblast cells prior to gastrulation, it has been suggested that it may retain a reservoir of stem cells throughout pregnancy (Ilancheran et al., 2007). Pre-clinical and clinical studies have demonstrated multiple uses for amniotic membrane stem cells in tissue repair, such as corneal tissue (Shimmura and Tsubota, 2002), spinal cord injury (Sankar and Muthusamy, 2003), brain infarction (Sakuragawa et al., 1997) and Parkinson's disease (Kakishita et al., 2003). Bailo et al. (2004) isolated and characterized amniotic and chorionic cells from human full-term placentas, which suggested that both cell types may represent an advantageous source of progenitor cells. Indeed, the HAM is becoming appreciated as an alternative to bone marrow for adult MSCs for regenerative medicine.

Because fetal tissues are routinely discarded post-partum, HAMs have proved to be abundant, inexpensive and easily obtained with a virtually limitless availability, negating any need for mass tissue banking (Chang et al., 2010, Toda et al., 2007, Niknejad et al., 2008, Hennerbichler et al., 2007 and Wilshaw et al., 2006). Moreover, this tissue provides efficiency in MSC recovery with noninvasive and safe procedures (Alviano et al., 2007). A major advantage of cells isolated from the HAM is that they are harvested after birth and can be cryogenically stored to be available in a timely manner for patient therapy after being thawed and expanded for use in tissue engineering, cell transplantation and gene therapy. Therefore, the HAM represents a very useful source of progenitor cells for a variety of applications. Because human embryos are not sacrificed for the isolation of progenitor cells from HAMs, the current controversies associated with the use of human embryonic stem cells can be avoided (Chang et al., 2010, Insausti et al., 2010, Toda et al., 2007 and Kim et al., 2009).

This fetal tissue expresses only moderate levels of the major histocompatibility complex (MHC) class I and MHC class II antigens on its surface. Therefore, hAECs and hAMSCs seem to be immuneprivileged; thus, suitable for allo-transplantation and regenerative medicine (Wei et al., 2009 and Kim et al., 2009).

In the present review, we focused the localization, isolation, quantification and phenotypic characterization of HAM-derived cells (hAECs and hAMSCs) and summarized their in vitro differentiation potential useful for regenerative medicine and cell therapy.

\section{Localization of human amniotic membrane-derived cells}

Location of HAM-derived cells in healthy human amniotic membranes stained with hematoxylin-eosin or Masson's Trichrome may be studied by histochemical and immunohistochemical techniques. The HAM contains two different cell types, hAECs and hAMSCs, from different embryological origins (Alviano et al., 2007 and Wolbank et al., 2007). The hAECs forms a continuous monolayer of embryonic ectodermally derived epithelium uniformely arranged on the basement membrane (BM) in contact with the amniotic fluid (Tamagawa et al., 2008) (Fig. 3A and B). The hAECs are positive for the epithelial 
markers cytokeratin 1, 2, 3, 4, 5, 6, 7, 8, 10, 13, 14, 15, 16 and 19 (Díaz-Prado et al., 2010a) (Fig. 3C), which confirms its epithelial nature. BM is one of the thickest membranes found in any human tissue that contains different types of collagens (Fig. 3D), fibronectin, nidogen, laminin, proteoglycans and hyaluronan, as well as growth factors (Niknejad et al., 2008, Harijadi et al., 2006 and Jin et al., 2007). hAMSCs are derived from embryonic mesoderm (Tamagawa et al., 2008) and are sparsely distributed in the stroma underlying the amnion epithelium (Bilic et al., 2008). An immunofluorescence study demonstrated that BM contains hAMSCs since they express common and well defined human MSC markers previously described for bone marrow MSCs such as CD44, CD90, CD105 and CD271 indicating that BM contains cell having stem-cell characteristics (Fig. 3E). The same study corroborated that hAECs contain positive cells for MSCs markers such as CD105 (Díaz-Prado et al., 2010b), indicating that the HAM contains at least two different cell types having stem-cell characteristics.
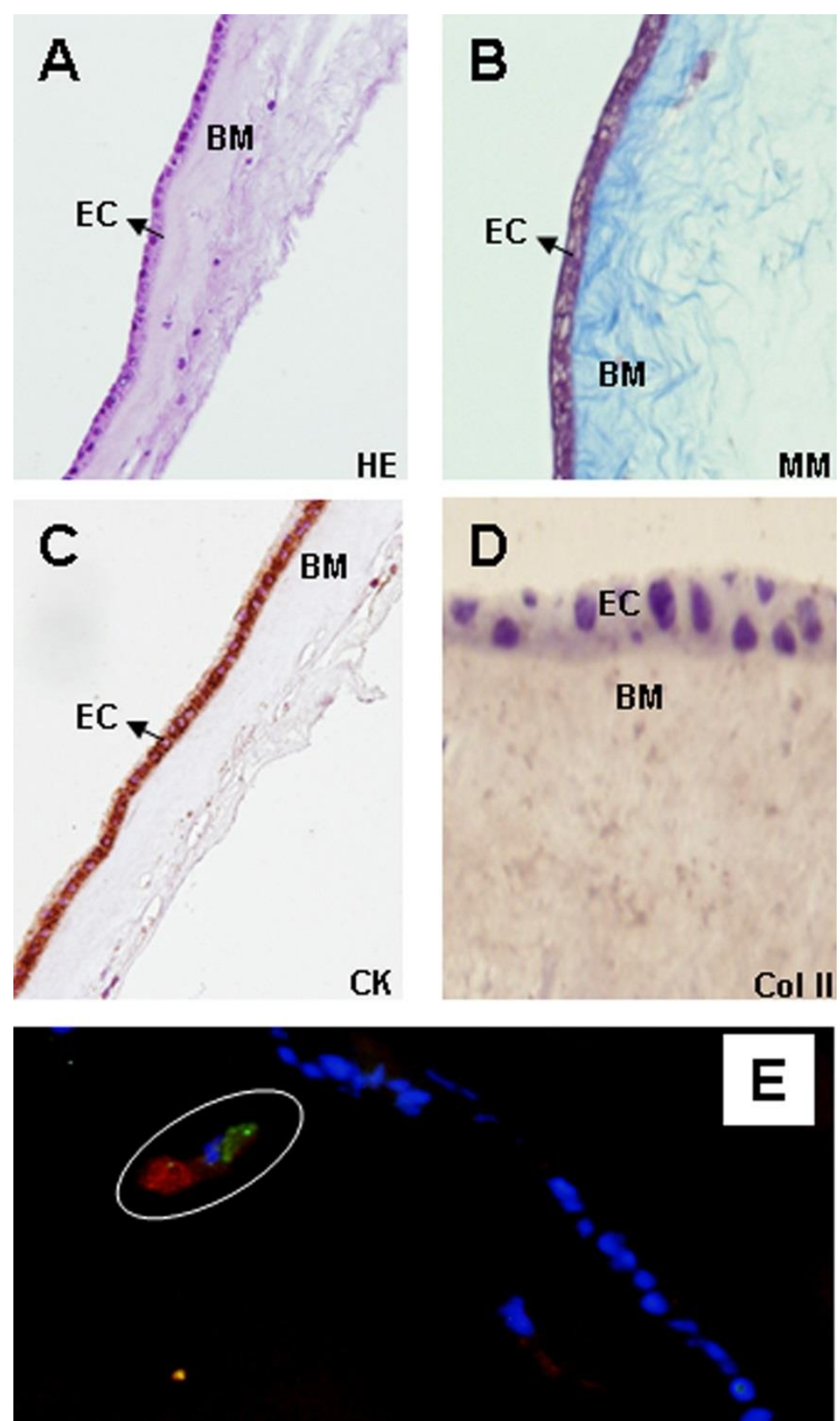

Fig. 3. Histological characterization of human amnion-derived cells. Sections of healthy HAM stained with H-E (A) and MM (B), immunohistochemistry for CK (C) and Col II (D) and by immunofluorescence for CD90 and CD105 (E). In (E) nuclei were counterstained with 4',6-diamidino-2-phenylindole (DAPI). BM indicates the thick basement membrane, and EC, the epithelial cells from extra-embryonic ectoderm. CK, cytokeratins. Original magnifications: (A) 100×, (B) 400×, (C-E) 200×. 


\section{Isolation and cultivation of cells from human amniotic membrane}

Cells from the mesenchymal and epithelial regions of the amnion can be isolated easily. Different methods to isolate HAM-derived cells have been published (Dazzi and Marelli-Berg, 2008, Parolini et al., 2008, Alviano et al., 2007, Soncini et al., 2007, Miki et al., 2007a, Miki and Strom, 2006 and Bailo et al., 2004). All of them start with a mechanical separation of the amniotic membrane from the underlying chorion through the spongy layer (Insausti et al., 2010), followed by a digestion with trypsin, dispase or other digestive enzymes, in different concentrations and for different periods of time, to release the hAECs from the basal membrane. hAMSCs can be subsequently released through subsequent digestion with collagenase (Parolini et al., 2009), alone or combined with DNAase (Steigman and Fauza, 2007). hAECs are small-size cells that are easy to expand in vitro for at least 3 passages without morphological changes, they grow in a lattice and have the typical cuboid morphology of epithelial cells (Fig. 4A). These cells generally have a central or eccentric nucleus, one or two nucleoli and abundant cytoplasm, usually vacuolated (Miki et al., 2007a). The hAMSCs cells have fibroblast-like cell morphology (Fig. 4B) and after 3 to 4 weeks of culture it is possible to obtain a population of adherent mesenchymal cells morphologically identical to MSCs isolated from bone marrow. These stromal cells are easy to expand in vitro for at least 9 passages without morphological changes. hAECs and hAMSCs can be grown in Dulbecco modified Eagle's media (DMEM) supplemented with $20 \%$ fetal bovine serum (FBS) and $1 \%$ penicillin-streptomycin (P/E) and seeded into culture flasks. Both populations should be expanded in a humidified $5 \% \mathrm{CO}_{2}$ atmosphere at $37^{\circ} \mathrm{C}$. After the isolation of both cell types it is advisable to perform immunohistochemical stainings (e.g. for cytokeratin 7, CK7) to demonstrate the purity of both populations. In this regard, only hAECs may be positive for this or other epithelial markers (Fig. 5). A recent study (Díaz-Prado et al., 2010a) compared two previously published protocols for the isolation of hAMSCs (Soncini et al., 2007 and Alviano et al., 2007), including their phenotypic characterization and in vitro potential for differentiation toward osteogenic, adipogenic and chondrogenic mesodermal lineages. Both protocols resulted in the isolation and culture of cells attached to the culture flask with fibroblast-like cell morphology. Quantitative studies showed that Soncini's protocol typically showed an increase in the hAMSCs isolation yield of almost ten fold with regard to Alviano's protocol. Also, the former protocol allowed the isolation and expansion of a larger number of cells in a very short time period. This ready and rapid availability of cells is one criteria required of a source of MSCs for it to be considered for cell transplantation.

A

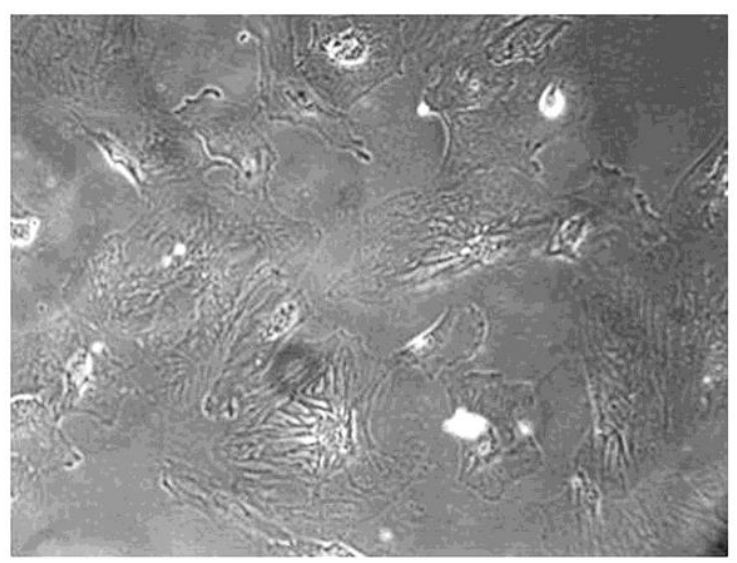

B

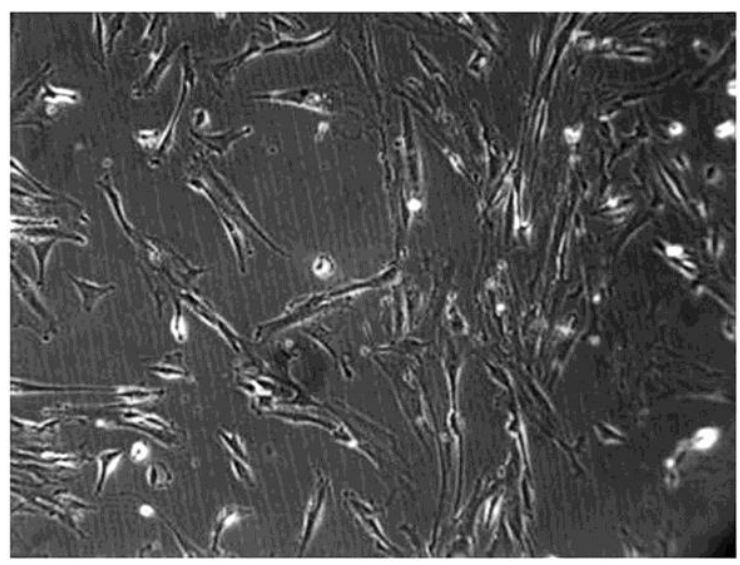

Fig. 4. Morphology of cultured hAECs (A) and hAMSCs (B) isolated from human amniotic membrane. Original magnifications: $100 \times$. 

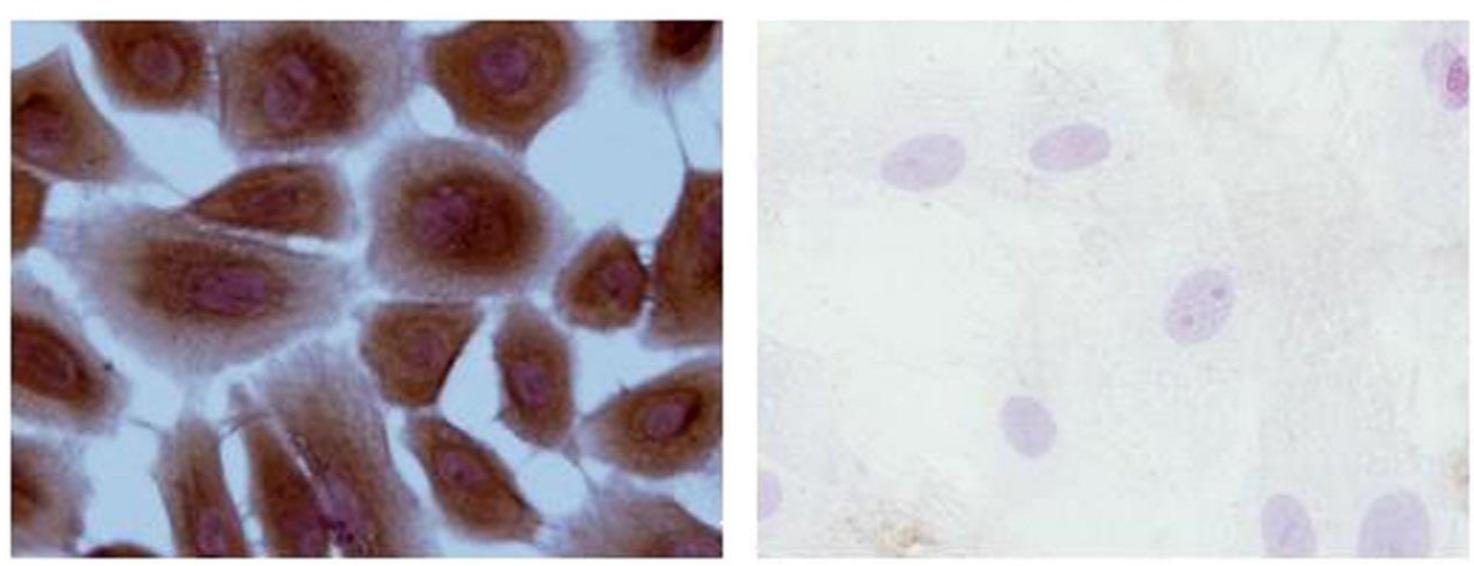

Fig. 5. Immunohistochemical stainings for CK7 expression in cultured HAECs (A) and hAMSCs (B). Original magnifications: $400 \times$.

There is a contradiction with the passage number at which HAM-derived cells stop proliferation. Based on the literature, proliferation slows down with every passage and cells settle into senescence until proliferation ceases. For example, Miki et al. (2007a) and Parolini et al. (2008) state that hAECs grow normally for 2 to 6 passages before proliferation ceases. On the contrary Bilic et al. (2008) confirmed that hAECs and hAMSCs proliferation almost stops beyond passage 5 whereas Toda et al. (2007) postulated that hAECs senescence is reached at lower passages, P3 or P4. However Alviano et al. (2007) and Soncini et al. (2007) indicated that hAMSCs are easily expanded in vitro for at least 15 passages without any visible morphological alterations but they used cells not exceeding P4 for cell characterization and multilineage differentiation potential studies.

A comparison between placental cells and bone marrow-derived mesenchymal stem cells (BM-MSCs) was the aim of the paper published by Barlow et al. (2008). These authors compared human placentaderived MSCs (the placental tissue included amnion, chorion and decidua) and human bone marrowderived MSC in terms of cell characteristics, optimal growth conditions, mesodermal lineage differentiation and in vivo safety specifically to determine if human placenta-derived MSCs could represent a source of human MSC for clinical trials. They demonstrated that both populations were similar in terms of growth condition requirements and in terms of subsequent biological characterization. However both populations differed with respect to their proliferation capabilities at different seeding densities. In this regard human bone marrow-derived MSCs proliferated more slowly than human placenta-derived MSCs in every experiment. Also the latter had greater long-term growth ability than the former. Moreover MSCs from both sources exhibited similar morphology, size and cell surface phenotype and mesodermal differentiation ability with the exception that human placenta-derived MSC consistently appeared less able to differentiate to the adipogenic lineage. In line with the results obtained these authors suggested that human placenta is an acceptable alternative source for human MSC.

\section{Characterization of cells isolated from human amniotic membrane}

Immunophenotypic characterization of hAMSCs demonstrate the presence of the common well defined human MSC markers (CD90, CD44, CD73, CD166, CD105 and CD29), described for bone marrow with the absence of the hematopoietic markers (CD34 and CD45) and the concomitant lack of monocyte (CD114), macrophage (CD11) and fibroblast markers (Insausti et al., 2010, Kobayashi et al., 2008 and Mihu et al., 2009). This antigen expression pattern is consistent with data published for stem cells isolated from various regions of the full-term placenta (Bilic et al., 2008, Bailo et al., 2004, Kobayashi et al., 2008, Barlow et al., 2008 and Mihu et al., 2009). hAMSCs also express low levels of HLA-ABC, but do not express HLA-DR, indicating that these stromal cells may be useful in clinical transplantation procedures (Parolini et al., 2009).

hAECs are positive for desmin and vimentin (Toda et al., 2007) and also for the same markers as hAMSCs (Díaz-Prado et al., 2010b). Therefore hAECs also had an antigen expression profile characteristic of culture-expanded MSCs (Bilic et al., 2008). Phenotypes of both cell populations, hAECs and hAMSCs, are maintained from passage P0 through passage P9 (Díaz-Prado et al., 2010b). It is 
important to note that in culture although both populations show and maintain a similar marker profile for mesenchymal progenitors there are many differences between them in cell shape and cell arrangement (Díaz-Prado et al., 2010b and Bilic et al., 2008).

Ilancheran et al. (2007) showed that hAECs expressed surface markers that are normally present on embryonic stem and germ cells such as SSEA3 (stage specific embryonic antigen 3), SSEA4, TRA-1-60 (tumor rejection antigen) and TRA-1-81 and other antigens such as the ABCG 2/BCRP (a member of the ATP-binding cassette superfamily), CD9, CD24, E-Cadherin, Integrin $\alpha 6$ and $\beta$ and c-met (receptor growth factor of the hepatocyte) (Niknejad et al., 2008 and Insausti et al., 2010). These epithelial cells also express transcription factors specific for pluripotential stem cells such as Oct4 (octamer binding protein 4), NANOG, SOX2 (SRY-related HMG-box gene 2) and REX-1 (Parolini et al., 2009, Miki et al., 2007b, Miki et al., 2005 and Miki and Strom, 2006). hAMSCs are also positive for these pluripotency markers but positivity for embryonic stem cell markers, SSEA-3 or SSEA-4, remains debated (Parolini et al., 2009).

Parolini et al. (2009) published a comparison of key features of human amniotic membrane-derived cells and human BM-MSCs (Table 1). These authors postulated that BM-MSCs have a higher cell doubling time that hAECs, while for the hAMSC this time was not reported yet. Regarding the maximum number of passages it ranges from 5 to 10 for hAMSCs, 10 to 20 for BM-MSCs and 30 for hAECs. In vitro differentiation potential toward endodermal, mesodermal and ectodermal lineages was also reported for the three cell types.

Table 1. Comparison of cell doubling time, maximum numbers of passages and differentiation potential of hAECs, hAMSCs and BM-MSCs. Data taken from Parolini et al. (2009).

\begin{tabular}{llll}
\hline Cell type & Cell doubling time & $\begin{array}{l}\text { Maximum number of } \\
\text { passages }\end{array}$ & Differentiation potential \\
\hline hAECs & $\begin{array}{l}\text { At 5th passage: } \\
\text { 24 h. }\end{array}$ & 30 & $\begin{array}{l}\text { In vitro differentiation toward endodermal, mesodermal and } \\
\text { ectodermal lineages. }\end{array}$ \\
& $\begin{array}{l}\text { At } 30 \text { th passage: } \\
18 \mathrm{~h} .\end{array}$ & $5-10$ & $\begin{array}{l}\text { In vitro differentiation toward endodermal, mesodermal and } \\
\text { ectodermal lineages. } \\
\text { In vitro differentiation toward endodermal, mesodermal and } \\
\text { ectodermal lineages. }\end{array}$ \\
hAMSCs & Not reported. & $10-20$ &
\end{tabular}

\section{Differentiation potential of amniotic cells}

The pluripotency of hAECs was supported by a study by Tamagawa et al. (2004). These scientific created a xenogeneic chimera with hAECs and mouse embryonic stem cells in vitro. This chimera gives rise to cells of all germ layers. Later studies have corroborated the ability of hAECs to in vitro differentiate into cells from the three germ layers (Insausti et al., 2010, Ilancheran et al., 2007 and Miki et al., 2005).

hAECs have characteristics of neural progenitor cells since these epithelial cells express some differentiation markers for neural stem, neuron and glial cells such as nestine, GAD (glutamate decarboxylase), GFAP (glial fibrillary acidic protein) and CNP (cyclic nucleotide phosphodiesterase) (Miki et al., 2005). Elwan and Sakuragawa (1997) and Kakishita et al. (2000), demonstrated the differentiation of the epithelial cells to neural cells (ectodermal lineage) with capacity to synthesize and release acetylcholine, catecholamines and dopamine, suggesting their possible utility in the treatment of neural degenerative diseases. In this regard, several studies have already been published showing promising results in animal models with Parkinson's disease and Mucopolysaccaridosis type VII. Studies of intracerebral grafting of hAECs for the treatment of a mouse model of Parkinson's disease showed that these epithelial cells can synthesize and release catecholamine and neurotrophic factors such as nerve growth factor, neurotrophin-3 and brain-derived neurotrophic factor (Kakishita et al., 2003, Kakishita et al., 2000 and Uchida et al., 2000). Kosuga et al. (2000) suggested that transplantation of hAECs transduced with adenoviral vectors can be employed for the treatment of congenital lysosomal storage disorders.

Hepatic differentiation (endodermal lineage) of hAECs was also reported by Sakuragawa et al. (2000). These authors demonstrated that cultivated hAECs produced albumin and $\alpha$-fetoprotein; and that 
hepatocyte-like cells, positive for albumin and $\alpha$-fetoprotein, could be identified integrated in the liver parenchyma of mice with severe combined immunodeficiency (SCID), after the transplantation of hAECs in the liver. Later studies demonstrated that these epithelial cells also displayed other functional properties associated with hepatocytes, such as glycogen storage and expression liver-enriched transcription factors, such as hepatocyte nuclear factor (HNF) $3 \gamma$ and HNF4 $\alpha$, CCAAT/enhancer-binding protein (CEBP $\alpha$ and $\beta$ ) and several of the drug metabolizing genes (cytochrome P450) (Miki et al., 2005, Takashima et al., 2004 and Davila et al., 2004). These findings suggest the potential utility of hAECs for restore hepatic tissues that have been diseased or injured. Differentiation of hAECs to another endodermal lineage, pancreatic, was also reported. Wei et al. (2003) cultured these epithelial cells in the presence of nicotinamide to induce pancreatic differentiation and they observed that the resulting cells expressed insulin. Subsequent transplantation of these insulin-expressing cells in the spleen of diabetic SCID mice normalized the levels of serum glucose for several months after the transplant, indicating the therapeutic potential of hAECs to treat diabetes mellitus type I. Later, Miki et al. (2005) showed by RT-PCR analysis that, after pancreatic differentiation, hAECs express pancreatic $\alpha$ and $\beta$ cell markers such as the transcription factors PDX-1 (pancreatic duodenum homeobox 1), PAX-6 (paired box homeotic gene 6) and NKX2.2 (NK2 transcription factor-related locus 2) and the mature hormones insulin and glucagon.

The differentiation of hAECs to cardiac cells (mesodermal lineage) was first evaluated by Miki et al. (2005). They demonstrated by RT-PCR that cardiac-specific genes atrial and ventricular myosin light chain 2 (MLC-2A and MLC-2V) and the transcription factors GATA-4 and Nkx 2.5 are expressed or induced in hAECs cultured in media supplemented with ascorbic acid for 14 days. The immunohistochemical analysis of alpha-actinin expression showed a staining pattern very similar to the one reported for hESC-derived cardiomyocytes. Differentiation of hAECs to another mesodermal lineages (Fig. 6 and Fig. 7) was reported by Ilancheran et al. (2007), who showed that native hAECs can differentiate into cells with a phenotype and markers characteristic of mesodermal-derived myocytes, osteocytes and adipocytes.

A

DMEM 21

C hAMSC AR

B

DMEM 21

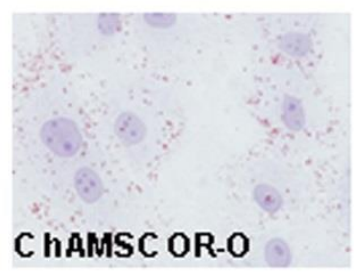

OSTEOGENESIS

DIF Osteo

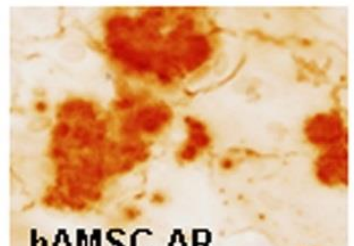

ADIPOGENESIS

DIF Adipo

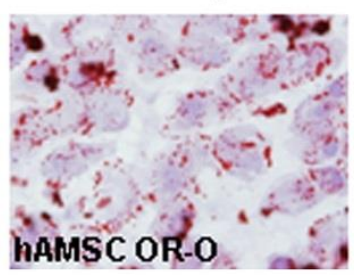

DMEM 21

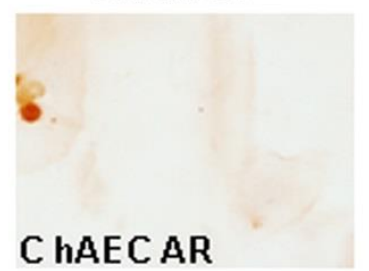

DMEM 21

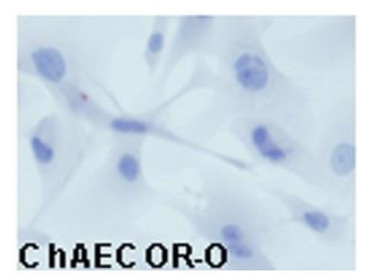

DIF Osteo

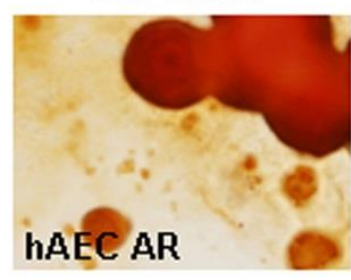

DIF Adipo

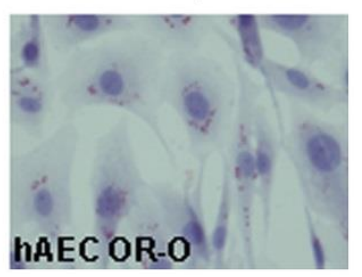

Fig. 6. Osteogenic (DIF Osteo) and adipogenic (DIF Adipo) differentiation of human amnion mesenchymal stromal cells (hAMSCs) and human amnion epithelial cells (hAECs) with their respective controls (C hAMSC and C hAEC) grown for 21 days in Dulbecco's Modified Eagle Medium (DMEM 21). The presence of the calcium deposits characteristic of osteoblasts was detected using Alizarin Red (AR) stain (A). The presence of adipocytes was assessed by detection of lipid drops using Oil Red O (OR-O) stain (B). Original magnifications: $400 \times$. 


\section{CHONDROGENESIS}
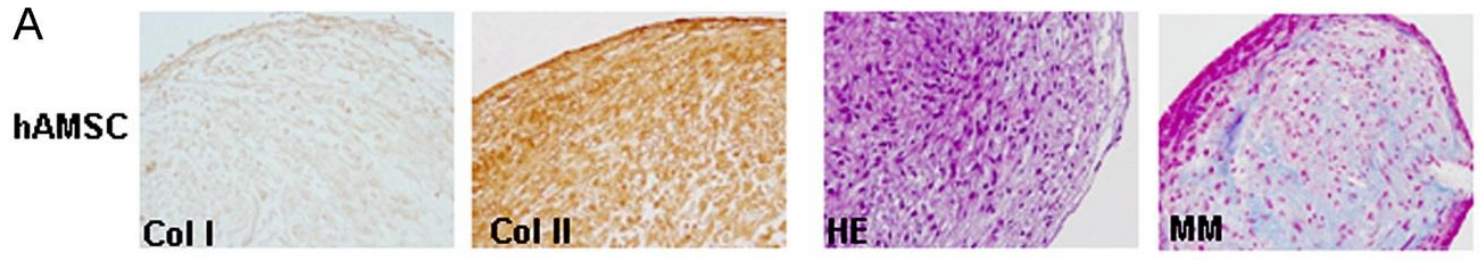

B
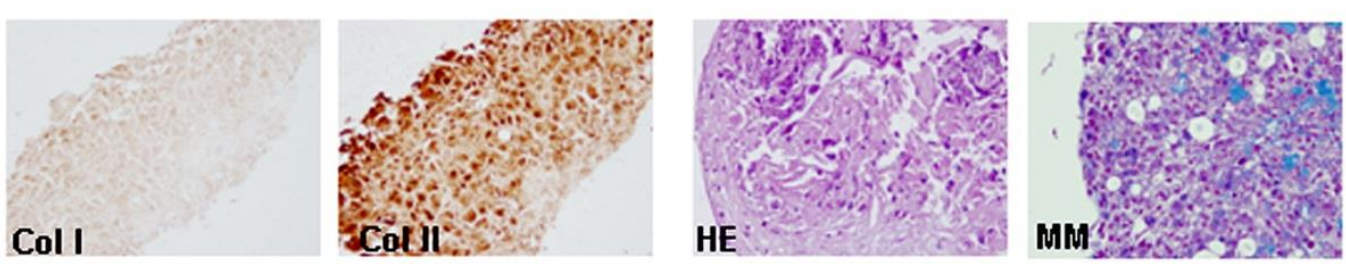

Fig. 7. Chondrogenic differentiation, assessed by micropellet formation, of hAMSCs [A] and hAECs [B]. Original magnifications: $200 x$.

MSCs from different parts of the placenta have been shown to differentiate into chondrogenic, osteogenic, endothelial, hepatocytic, myogenic and neurogenic lineages, but with appreciable differences among cell types depending on the placental tissue source (Chang et al., 2010, Insausti et al., 2010, Portmann-Lanz et al., 2006, Tamagawa et al., 2007, Tamagawa et al., 2008, Kobayashi et al., 2008, In’t Anker et al., 2004, Alviano et al., 2007, Wei et al., 2009, Mihu et al., 2009, Pasquinelli et al., 2007, Soncini et al., 2007 and Sakuragawa et al., 2004).

hAMSCs differentiation to neuronal lineage have been demonstrated by the fact that these cells express neuronal markers (Nestin, Musashi 1, neuron-specific enolase, neurofilament medium, microtubule-associated protein [MAP]-2 and Neu-N) and glial (GFAP) markers, after their culture in specific neural-induction media (Sakuragawa et al., 2004, Portmann-Lanz et al., 2006, Kim et al., 2007 and Tamagawa et al., 2008).

Tamagawa et al. (2007) showed that hAMSCs were able to differentiate into cells with characteristics of hepatocytes. In this regard, native cells expressed typical hepatocytic mRNA such as albumin, CK (cytokeratin) 18, $\alpha$-fetoprotein, $\alpha$ 1-antitrypsin and HNF-4 $\alpha$ but only glucose- 6 -phosphatase and ornithine transcarbamylase expression and glycogen storage were observed after in vitro hepatic induction.

Regarding hAMSCs differentiation towards mesodermal lineage (Fig. 6 and Fig. 7), In'tAnker et al. (2004) demonstrated the potential of hAMSCs to differentiate into osteogenic and adipogenic cells. After osteogenic differentiation hAMSCs suffered morphologic changes and showed calcium deposits when they were stained with von Kossa's dye. On the other hand, after adipogenic differentiation hAMSCs become multi vacuolated cells that were stained with Red oil O stain. Later, Portmann-Lanz et al. (2006) showed the capacity of these stromal cells for differentiation to chondrogenic and myogenic lineages. Chondrogenic differentiation of these cells was demonstrated by the presence of abundant collagen in the extracellular matrix by means of Alcino's blue dye. Myogenic differentiation of hAMSCs has been determined by RT-PCR since Portmann-Lanz et al. (2006) demonstrated the mRNA expression of myogenic transcription factors such as Myo D and Myogenin and the protein expression of desmine in hAMSCs cultured in differentiation media. Alviano et al. (2007) confirmed these results and also was the first in demonstrate the angiogenic differentiation potential of these cells. This latter study revealed that hAMSCs, after culture in induction media with VEGF, expressed endothelial-specific markers such as the receptors of the vascular endothelial growth factor 1 and 2 (FLT-1, KDR), ICAM-1 as well as the appearance of CD34 and von Willebrand Factor (vWF) positive cells. Regarding cardiomyogenic potential, it has been demonstrated that hAMSCs expressed cardiac-specific genes such as GATA4, MLC-2a (myosin light chain), MLC-2v, cTnI and cTnT (Tanaka et al., 1999 and Zhao et al., 2005) after cardiomyogenic induction. Zhao et al. (2005) showed that after hAMSCs transplantation into the myocardial infarcts in rat hearts, these cells survived in the scar tissue for at least 2 months and differentiated into cardiomyocyte-like cells. On the other hand, spontaneous differentiation of hAMSCs towards myofibroblasts has also been observed after their culture in standard medium (DMEM/FBS) within 2 passages (Li et al., 2008) 


\section{Summary}

HAM, an abundant, inexpensive and easily obtained tissue that is discarded post-partum, represents a valuable material for tissue banking and a viable alternative to other synthetic or natural scaffolds. Amnion contains two different cell types, hAECs and hAMSCs, which display characteristic properties of stem cells. Both amnion-derived populations are easily isolated from HAM and have the capacity to differentiate in vitro into all three germ layers: endoderm, mesoderm and ectoderm, suggesting their great interest in the fields of cell therapy and regenerative medicine. The unlimited availability of HAMs, the high efficiency in MSC recovery with non-invasive and safe procedures, the minimal ethical and legal issues associated with its use and the low immunogenicity of amnion-derived cells, make them an alternative source of MSCs. More studies should be carried out to determine whether such in vitrodifferentiated cells can function in vivo.

\section{Acknowledgements}

This study was supported by grants: Servizo Galego de Saúde, Xunta de Galicia (PS07/84), Cátedra Bioiberica de la Universidade da Coruña and Instituto de Salud Carlos III CIBER BBNCB06-01-0040; Ministerio Ciencia en InnovacionPLE2009-0144; Fondo Investigacion Sanitaria-PI 08/2028 with participation of fundus from FEDER (European Community), Silvia Diaz-Prado is beneficiary of an Isidro Parga Pondal contract from Xunta de Galicia, A Coruna, Spain.

\section{References}

Abdallah et al., 2005. BM Abdallah, M Haack-Sorensen, JS Burns, B Elsnab, F Jakob, P Hokland, M. Kassem. Maintenance of differentiation potential of human bone marrow mesenchymal stem cells immortalized by human telomerase reverse transcriptase gene despite [corrected] extensive proliferation. Biochem. Biophys. Res. Commun., 326 (2005), pp. 527-538.

Alsalameh et al., 2004. S Alsalameh, R Amin, T Gemba, M. Lotz. Identification of mesenchymal progenitor cells in normal and osteoarthritic human articular cartilage. Arthritis Rheum., 50 (2004), pp. 1522-1532.

Alviano et al., 2007. F Alviano, V Fossati, C Marchionni, M Arpinati, L Bonsi, M Franchina, G Lanzoni, S Cantoni, C Cavallini, F Bianchi, PL Tazzari, G Pasquinelli, L Foroni, C Ventura, A Grossi, GP. Bagnara. Term amniotic membrane is a high throughput source for multipotent mesenchymal stem cells with ability to differentiate into endothelial cells in vitro. BMC Dev. Biol., 7 (2007), p. 11.

Bailo et al., 2004. M Bailo, M Soncini, E Vertua, PB Signoroni, S Sanzone, G Lombardi, D Arienti, F Calamani, D Zatti, P Paul, A Albertini, F Zorzi, A Cavagnini, F Candotti, GS Wengler, O. Parolini. Engraftment potential of human amnion and chorion cells derived from term placenta. Transplantation, 78 (2004), pp. 1439-1448.

Baksh et al., 2007. D Baksh, R Yao, RS. Tuan. Comparison of proliferative and multilineage differentiation potential of human mesenchymal stem cells derived from umbilical cord and bone marrow. Stem Cells, 25 (2007), pp. $1384-1392$.

Banfi et al., 2000. A Banfi, A Muraglia, B Dozin, M Mastrogiacomo, R Cancedda, R. Quarto. Proliferation kinetics and differentiation potential of ex vivo expanded human bone marrow stromal cells: implications for their use in cell therapy. Exp. Hematol., 28 (2000), pp. 707-715.

Barlow et al., 2008. S Barlow, G Brooke, K Chatterjee, G Price, R Pelekanos, T Rossetti, M Doody, D Venter, S Pain, K Gilshenan, K. Atkinson. Comparison of human placenta- and bone marrow-derived multipotent mesenchymal stem cells. Stem Cells Dev., 17 (2008), pp. 1095-1108

Bianco and Robey, 2001. P Bianco, PG. Robey. Stem cells in tissue engineering. Nature, 414 (2001), pp. 118-121.

Bilic et al., 2008. G Bilic, SM Zeisberger, AS Mallik, R Zimmermann, AH. Zisch. Comparative characterization of cultured human term amnion epithelial and mesenchymal stromal cells for application in cell therapy. Cell Transplant, 17 (2008), pp. 955-968.

Bonab et al., 2006. MM Bonab, K Alimoghaddam, F Talebian, SH Ghaffari, A Ghavamzadeh, B. Nikbin. Aging of mesenchymal stem cell in vitro. BMC Cell Biol., 7 (2006), pp. 14-20.

Brandt and Mazzuca, 2006. KD Brandt, SA. Mazzuca. Experience with a placebo-controlled randomized clinical trial of a disease-modifying drug for osteoarthritis: the doxycycline trial. Rheum. Dis. Clin. North Am., 32 (2006), pp. $217-234$.

Brittberg et al., 1994. M Brittberg, A Lindahl, A Nilsson, C Ohlsson, O Isaksson, L. Peterson. Treatment of deep cartilage defects in the knee with autologous chondrocyte transplantation. N. Engl. J. Med., 331 (1994), pp. 889895

Brooks, 2002. PM. Brooks. Impact of osteoarthritis on individuals and society: how much disability? Social consequences and health economic implications. Curr. Opin. Rheumatol., 14 (2002), pp. 573-577. Caplan, 1991. AI. Caplan. Mesenchymal stem cells. J. Orthop. Res., 9 (1991), pp. 641-650.

Chang et al., 2010. Y-J Chang, S-M Hwang, C-P Tseng, F-C Cheng, S-H Huang, L-F Hsu, L-W Hsu, M-S. Tsai. Isolation of mesenchymal stem cells with neurogenic potential from the mesoderm of the amniotic membrane. Cells Tissues Organs, 192 (2010), pp. 93-105. 
Davila et al., 2004. JC Davila, GG Cezar, M Thiede, S Strom, T Miki, J. Trosko. Use and application of stem cells in toxicology. Toxicol. Sci., 79 (2004), pp. 214-223.

Dazzi and Marelli-Berg, 2008. F Dazzi, F. Marelli-Berg. Mesenchymal stem cells for graft-versus-host disease: close encounters with T cells. Eur. J. Immunol., 38 (2008), pp. 1479-1482.

De Bari et al., 2001. C De Bari, F Dell'Acio, P Tylzanowski, FP. Luyten. Multipotent mesenchymal stem cells from adult human synovial membrane. Arthritis Rheum., 44 (2001), pp. 1928-1942.

Díaz-Prado et al., 2010a. S Díaz-Prado, E Muíños-López, T Hermida-Gómez, ME Rendal-Vázquez, I FuentesBoquete, FJ de Toro, FJ Blanco. Isolation and characterization of mesenchymal stem cells from human amniotic membrane. Tissue Eng. Part C Methods (2010), p. 1 August.

Díaz-Prado et al., 2010b. S Díaz-Prado, E Muíños-López, T Hermida-Gómez, ME Rendal-Vázquez, I FuentesBoquete, FJ de Toro, FJ Blanco. Multilineage differentiation potential of cells isolated from the human amniotic membrane. J. Cell Biochem., 111 (2010), pp. 846-857.

Díaz-Prado et al., 2010c. S Díaz-Prado, ME Rendal-Vázquez, E Muíños López, T Hermida-Gómez, M RodríguezCabarcos, I Fuentes-Boquete, FJ de Toro, FJ Blanco. Potential use of the human amniotic membrane as a scaffold in human articular cartilage repair. Cell Tissue Bank, 11 (2010), pp. 183-195.

Djouad et al., 2005. F Djouad, C Bony, T Häupl, G Uzé, N Lahlou, P Louis-Plence, F Apparailly, F Canovas, T Réme, J Sany, C Jorgensen, D. Noël. Transcriptional profiles discriminate bone marrow-derived and synoviumderived mesenchymal cells. Arthritis Res. Ther., 7 (2005), pp. 1304-1315.

Dominici et al., 2006. M Dominici, K Le Blanc, I Mueller, I Slaper-Cortenbach, F Marini, D Krause, R Deans, A Keating, Prockop Dj, E. Horwitz. Minimal criteria for defining multipotent mesenchymal stromal cells. The international society for cellular therapy position statement. Cytotherapy, 8 (2006), pp. 315-317.

Dounchis et al., 1997. JS Dounchis, RS Goomer, FL Harwood, M Khatod, RD Coutts, D. Amiel. Chondrogenic phenotype of perichondrium-derived chondroprogenitor cells is influenced by transforming growth factor-beta 1. J. Orthop. Res., 15 (1997), pp. 803-807.

Dua et al., 2004. H.S. Dua, J.A. Gomes, A.J. King, V.S. Maharajan. The amniotic membrane in ophthalmology. Surv. Ophthalmol., 49 (2004), pp. 51-77.

Elwan and Sakuragawa, 1997. MA Elwan, N. Sakuragawa. Evidence for synthesis and release of catecholamines by human amniotic epithelial cells. Neuroreport, 8 (1997), pp. 3435-3438.

Fauza, 2004. D. Fauza. Amniotic fluid and placental stem cells. Best Pract. Res. Clin. Obstet. Gynaecol., 18 (2004), pp. 877-891.

Fickert et al., 2003. S Fickert, J Fiedler, RE. Brenner. Identification, quantification and isolation of mesenchymal progenitor cells from osteoarthritic synovium by fluorescence automated cell sorting. Osteoarthritis Cartilage, 11 (2003), pp. 790-800.

Fuentes-Boquete et al., 2007. IM Fuentes-Boquete, MC Arufe Gonda, S Díaz Prado, T Hermida Gómez, FJ de Toro Santos, FJ Blanco García. Tratamiento de lesiones del cartílago articular con terapia celular. Reumatol. Clin., 3 (2007), pp. S63-S69 3 Suppl.

Fuentes-Boquete et al., 2008. IM Fuentes-Boquete, MC Arufe Gonda, SM Díaz Prado, T Hermida Gómez, FJ de Toro santos, FJ Blanco. Cell and tissue transplant strategies for joint lesions. Open Transplantation J., 2 (2008), pp. 21-28.

Ganatra, 2003. M.A. Ganatra. Amniotic membrane in surgery. J. Pak. Med. Assoc., 53 (2003), pp. 29-32. Gomes et al., 2005. J.A. Gomes, A. Romano, M.S. Santos, H.S. Dua. Amniotic membrane use in ophthalmology. Curr. Opin. Ophthalmol., 16 (2005), pp. 233-240.

Han et al., 2008. EH Han, WC Bae, ND Hsieh-Bonassera, VW Wong, BL Schumacher, S Görtz, K Masuda, WD Bugbee, RL. Sah. Shaped, stratified, scaffold-free grafts for articular cartilage defects. Clin. Orthop. Relat. Res., 466 (2008), pp. 1912-1920.

Hao et al., 2000. Y. Hao, D.H. Ma, D.G. Hwang, W.S. Kim, F. Zhang. Identification of antiangiogenic and antiinflammatory proteins in human amniotic membrane. Cornea, 19 (2000), pp. 348-352.

Hennerbichler et al., 2007. S Hennerbichler, B Reichl, D Pleiner, C Gabriel, J Eibl, H. Redl. The influence of various storage conditions on cell viability in amniotic membrane. Cell Tissue Bank, 8 (2007), pp. 1-8.

Hombach-Klonisch et al., 2008. S Hombach-Klonisch, S Panigrahi, I Rashedi, A Seifert, E Alberti, P Pocar, M Kurpisz, K Schulze-Osthoff, A Mackiewicz, M. Los. Adult stem cells and their trans-differentiation potentialperspectives and therapeutic applications. J. Mol. Med., 86 (2008), pp. 1301-1314.

Ilancheran et al., 2007. S Ilancheran, A Michalska, G Peh, EM Wallace, M Pera, U. Manuelpillai. Stem cells derived from human fetal membranes display multilineage differentiation potential. Biol. Reprod., 77 (2007), pp. 577588.

Ilancheran et al., 2009. S Ilancheran, Y Moodley, U. Manuelpillai. Human fetal membranes: a source of stem cells for tissue regeneration and repair?. Placenta, 30 (2009), pp. 2-10.

Im et al., 2001. GI Im, DY Kim, JH Shin, CW Hyun, WH. Cho. Repair of cartilage defect in the rabbit with cultured mesenchymal stem cells from bone marrow. J. Bone Joint Surg. Br., 83 (2001), pp. 289-294.

Insausti et al., 2010. CL Insausti, M Blanquer, P Bleda, P Iniesta, MJ Majado, G Castellanos, JM. Moraleda. The amniotic membrane as a source of stem cells. Histol. Histopathol., 25 (2010), pp. 91-98.

In’t Anker et al., 2004. PS In`t Anker, SA Scherjon, C Kleijburg-van der Keur, GM de Groot-Swings, FH Claas, WE Fibbe, HH Kanhai. Isolation of mesenchymal stem cells of fetal or maternal origin from human placenta. Stem Cells, 22 (2004), pp. 1338-1345.

In't Anker et al., 2003. PS In't Anker, WA Noort, AB Kruisselbrink, SA Scherjon, W Beekhuizen, R Willemze, HH Kanhai, WE. Fibbe. Nonexpanded primary lung and bone marrow-derived mesenchymal cells promote the 
engraftment of umbilical cord blood-derived CD34(+) cells in NOD/SCID mice. Exp. Hematol., 31 (2003), pp. $881-889$.

Ishiguro et al., 2002. N Ishiguro, T Kojima, R. Poole. Mechanism of cartilage destruction in osteoarthritis. Nagoya J. Med. Sci., 65 (2002), pp. 73-84.

Izadpanah et al., 2006. R Izadpanah, C Trygg, B Patel, C Kriedt, J Dufour, JM Gimble, BA. Bunnell. Biologic properties of mesenchymal stem cells derived from bone marrow and adipose tissue. J. Cell Biochem., 99 (2006), pp. $1285-1297$.

Jin et al., 2007. CZ Jin, SR Park, BH Choi, KY Lee, CK Kang, BH. Min. Human amniotic membrane as a delivery matrix for articular cartilage repair. Tissue Eng., 13 (2007), pp. 693-702.

Jung et al., 2009. DI Jung, J Ha, BT Kang, JW Kim, FS Quan, JH Lee, EJ Woo, HM. Park. A comparison of autologous and allogenic bone marrow-derived mesenchymal stem cell transplantation in canine spinal cord injury. J. Neurol. Sci., 285 (2009), pp. 67-77.

Kakishita et al., 2000. K Kakishita, MA Elwan, N Nakao, T Itakura, N. Sakuragawa. Human amniotic epithelial cells produce dopamine and survive after implantation into the striatum of a rat model of Parkinson's disease: a potential source of donor for transplantation therapy. Exp. Neurol., 165 (2000), pp. 27-34.

Kakishita et al., 2003. K Kakishita, N Nakao, N Sakuragawa, T. Itakura. Implantation of human amniotic epithelial cells prevents the degeneration of nigral dopamine neurons in rats with 6-hydroxydopaminen lesions. Brain Res., 980 (2003), pp. 48-56.

Kastrinaki et al., 2008. M-C Kastrinaki, I Andreakou, P Charbord, HA. Papadaki. Isolation of human bone marrow mesenchymal stem cells using different membrane markers: comparison of colony/cloning efficiency, differentiation potential, and molecular profile. Tissue Eng. Part C Methods, 14 (2008), pp. 333-339.

Kim et al., 2007. J Kim, HM Kang, H Kim, MR Kim, HC Kwon, MC Gye, SG Kang, HS Yang, J. You. Ex vivo characteristics of human amniotic membrane-derived stem cells. Cloning Stem Cells, 9 (2007), pp. 581-594.

Kim et al., 2009. SS Kim, CK Song, SK Shon, KY Lee, CH Kim, MJ Lee, L. Wang. Effects of human amniotic membrane grafts combined with marrow mesenchymal stem cells on healing of full-thickness skin defects in rabbits. Cell Tissue Res., 336 (2009), pp. 59-66.

Kobayashi et al., 2008. M Kobayashi, T Yakuwa, K Sasaki, K Sato, A Kikuchi, I Kamo, Y Yokoyama, N. Sakuragawa. Multilineage potential of side population cells from human amnion mesenchymal layer. Cell Transplant., 17 (2008), pp. 291-301.

Koga et al., 2008. H Koga, M Shimaya, T Muneta, A Nimura, T Morito, M Hayashi, S Suzuki, YJ Ju, T Mochizuki, I. Sekiya. Local adherent technique for transplanting mesenchymal stem cells as a potential treatment of cartilage defect. Arthritis Res. Ther., 10 (2008), p. R84.

Kosuga et al., 2000. M Kosuga, S Takahashi, K Sasaki, S Enosawa, XK Li, S Okuyama, M Fujino, S Suzuki, M Yamada, N Matsuo, N Sakuragawa, T. Okuyama. Phenotype correction in murine mucopolysaccharidosis type VII by transplantation of human amniotic epithelial cells after adenovirus-mediated gene transfer. Cell Transplant., 9 (2000), pp. 687-692.

Kuo et al., 2006. CK Kuo, WJ Li, RL Mauck, RS. Tuan. Cartilage tissue engineering: its potential and uses. Curr. Opin. Rheumatol., 18 (2006), pp. 64-73.

Kuznetsov et al., 2001. SA Kuznetsov, MH Mankani, S Gronthos, K Satomura, P Bianco, PG. Robey. Circulating skeletal stem cells. J. Cell Biol., 153 (2001), pp. 1133-1140.

Le Blanc et al., 2005. K Le Blanc, C Götherström, O Ringdén, M Hassan, R McMahon, E Horwitz, G Anneren, O Axelsson, J Nunn, U Ewald, S Nordén Lindeberg, M Jansson, A Dalton, E Aström, M. Westgren. Fetal mesenchymal stem-cell engraftment in bone after in utero transplantation in a patient with severe osteogenesis imperfecta. Transplantation, 79 (2005), pp. 1607-1614.

Li et al., 2008. W Li, H He, YT Chen, Y Hayashida, SC. Tseng. Reversal of myofibroblasts by amniotic membrane stromal extract. J. Cell Physiol., 215 (2008), pp. 657-664.

Mankin, 1982. HJ. Mankin. The response of articular cartilage to mechanical injury. J. Bone Joint Surg. Am., 64 (1982), pp. 460-466.

Mareschi et al., 2001. K Mareschi, E Biasin, W Piacibello, M Aglietta, E Madon, F. Fagioli. Isolation of human mesenchymal stem cells: bone marrow versus umbilical cord blood. Haematologica, 86 (2001), pp. 1099-1100.

Matikainen and Laine, 2005. T Matikainen, J. Laine. Placenta-an alternative source of stem cells. Toxicol. Appl. Pharmacol., 207 (2 Suppl.) (2005), pp. 544-549.

McGuckin et al., 2005. CP McGuckin, N Forraz, MO Baradez, S Navran, J Zhao, R Urban, R Tilton, L. Denner. Production of stem cells with embryonic characteristics from human umbilical cord blood. Cell Prolif., 38 (2005), pp. 245-255.

Meller et al., 2000. D Meller, RT Pires, RJ Mack, F Figueiredo, A Heiligenhaus, WC Park, P Prabhasawat, T John, SD McLeod, KP Steuhl, SC. Tseng. Amniotic membrane transplantation for acute chemical or thermal burns. Ophthalmology, 107 (2000), pp. 980-989.

Mihu et al., 2009. CM Mihu, D Rus Ciucă, O Soritău, S Suşman, D. Mihu. Isolation and characterization of mesenchymal stem cells from the amniotic membrane. Rom. J. Morphol. Embryol., 50 (2009), pp. 73-77.

Miki et al., 2005. T Miki, T Lehmann, H Cai, DB Stolz, SC. Strom. Stem cell characteristics of amniotic epithelial cells. Stem Cells, 23 (2005), pp. 1549-1559.

Miki et al., 2007a. T Miki, F Marongiu, E Ellis, S. Strom. Isolation of amniotic epithelial stem cells. Curr. Protoc. Stem Cell Biol., 3 (2007) 1E.3.1-1E.3.9.

Miki et al., 2007b. T Miki, K Mitamura, MA Ross, DB Stolz, SC. Strom. Identification of stem cell marker-positive cells by immunofluorescence in term human amnion. J. Reprod. Immunol., 75 (2007), pp. 91-96. 
Miki and Strom, 2006. T Miki, SC. Strom. Amnion-derived pluripotent/multipotent stem cells. Stem Cell Rev., 2 (2006), pp. 133-142.

Minas and Chiu, 2000. T Minas, R. Chiu. Autologous chondrocyte implantation. Am. J. Knee Surg., 13 (2000), pp. 41-50.

Minguell et al., 2000. JJ Minguell, P Conget, A.. Erices. Biology and clinical utilization of mesenchymal progenitor cells. Braz. J. Med. Biol. Res., 33 (2000), pp. 881-887.

Morton and Dewhurst, 1986. KE Morton, CJ. Dewhurst. Human amnion in the treatment of vaginal malformations. Br. J. Obstet. Gynaecol., 93 (1986), pp. 50-54.

Mrugala et al., 2009. D Mrugala, N Dossat, J Ringe, B Delorme, A Coffy, C Bony, P Charbord, T Häupl, J-P Daures, D Noël, C. Jorgensen. Gene expression profile of multipotent mesenchymal stromal cells: identification of pathways common to TGF/3/BMP2-induced chondrogenesis. Cloning Stem Cells, 11 (2009), pp. 61-76.

Muraglia et al., 2000. A Muraglia, R Cancedda, R. Quarto. Clonal mesenchymal progenitors from human bone marrow differentiate in vitro according to a hierarchical model. J. Cell Sci., 113 (2000), pp. 1161-1166.

Nakahara et al., 1990. H Nakahara, SP Bruder, SE Haynesworth, JJ Holecek, MA Baber, VM Goldberg, AI. Caplan. Bone and cartilage formation in diffusion chambers by subcultured cells derived from the periosteum. Bone, 11 (1990), pp. 181-188.

Niknejad et al., 2008. H Niknejad, H Peirovi, M Jorjani, A Ahmadiani, J Ghanavi, AM. Seifalian. Properties of the amniotic membrane for potential use in tissue engineering. Eur. Cell Mater., 15 (2008), pp. 88-99.

Parolini et al., 2008. O Parolini, F Alviano, GP Bagnara, G Bilic, HJ Bühring, M Evangelista, S Hennerbichler, B Liu, M Magatti, N Mao, T Miki, F Marongiu, H Nakajima, T Nikaido, CB Portmann-Lanz, V Sankar, M Soncini, G Stadler, D Surbek, TA Takahashi, H Redl, N Sakuragawa, S Wolbank, S Zeisberger, A Zisch, SC. Strom. Concise review: isolation and characterization of cells from human term placenta: outcome of the first international workshop on placenta derived stem cells. Stem Cells, 26 (2008), pp. 300-311.

Parolini et al., 2009. O Parolini, M Soncini, M Evangelista, D. Schmidt. Amniotic membrane and amniotic fluidderived cells: potential tools for regeneative medicine?. Regen. Med., 4 (2009), pp. 275-291.

Parsch et al., 2004. D Parsch, J Fellenberg, TH Brummendorf, AM Eschlbeck, W. Richter. Telomere length and telomerase activity during expansion and differentiation of human mesenchymal stem cells and chondrocytes. J. Mol. Med., 82 (2004), pp. 49-55.

Pasquinelli et al., 2007. G Pasquinelli, P Tazzari, F Ricci, C Vaselli, M Buzzi, R. Conte. Ultrastructural characteristics of human mesenchymal stromal (stem) cells derived from bone marrow and term placenta. Ultrastruc. Pathol., 31 (2007), pp. 23-31.

Pittenger et al., 1999. MF Pittenger, AM Mackay, SC Beck, RK Jaiswal, R Douglas, JD Mosca, MA Moorman, DW Simonetti, S Craig, DR. Marshak. Multilineage potential of adult human mesenchymal stem cells. Science, 284 (1999), pp. 143-147.

Pittenger, 2008. MF. Pittenger. Mesenchymal stem cells from adult bone marrow. Methods Mol. Biol., 449 (2008), pp. 27-44.

Portmann-Lanz et al., 2006. CB Portmann-Lanz, A Schoeberlein, A Huber, R Sager, A Malek, W Holzgreve, DV. Surbek. Placental mesenchymal stem cells as potential autologous graft for pre- and perinatal neuroregeneration. Am. J. Obstet. Gynecol., 194 (2006), pp. 664-673.

Prockop, 1997. DJ. Prockop. Marrow stromal cells as stem cells for nonhematopoietic tissues. Science, 276 (1997), pp. 71-74.

Resinger et al., 2004. C Resinger, V Vécsei, S. Marlovits. Therapeutic options in the treatment of cartilage defects. Techniques and indications. Radiologe, 44 (2004), pp. 756-762.

Harijadi et al., 2006. Rinastiti M Harijadi, AL Santoso, W Sosroseno. Histological evaluation of rabbit gingival wound healing transplanted with human amniotic membrane. Int. J. Oral Maxillofac. Surg., 35 (2006), pp. 247251

Sakaguchi et al., 2005. Y Sakaguchi, I Sekiya, K Yagishita, T. Muneta. Comparison of human stem cells derived from various mesenchymal tissues: superiority of synovium as a cell source. Arthritis Rheum., 52 (2005), pp. $2521-2529$.

Sakuragawa et al., 2000. N Sakuragawa, S Enosawa, T Ishii, R Thangavel, T Tashiro, T Okuyama, S. Suzuki. Human amniotic epithelial cells are promising transgene carriers for allogenic cell transplantation into liver. J. Hum. Genet., 45 (2000), pp. 171-176.

Sakuragawa et al., 2004. N Sakuragawa, K Kakinuma, A Kikuchi, H Okano, S Uchida, I Kamo, M Kobayashi, Y. Yokoyama. Human amnion mesenchyme cells express phenotypes of neuroglial progenitor cells. J. Neurosci. Res., 78 (2004), pp. 208-214 Erratum in: J. Neurosci. Res. 2005; 79, 725.

Sakuragawa et al., 1997. N Sakuragawa, H Misawa, K Ohsugi, K Kakishita, T Ishii, R Thangavel, J Tohyama, M Elwan, Y Yokoyama, O Okuda, H Arai, I Ogino, K. Sato. Evidence for active acetylcholine metabolism in human amniotic epithelial cells: applicable to intracerebral allografting for neurologic disease. Neurosci. Lett., 232 (1997), pp. 53-56.

Samuel et al., 2008. GN Samuel, IH Kerridge, TA. O’Brien. Umbilical cord blood banking: public good or private benefit?. Med. J. Aust., 188 (2008), pp. 533-535.

Sankar and Muthusamy, 2003. V Sankar, R. Muthusamy. Role of human amniotic epithelial cell transplantation in spinal cord injury repair research. Neuroscience, 118 (2003), pp. 11-17.

Santos et al., 2005. MS Santos, JAP Gomes, AL Hofling-Lima, LV Rizzo, AC Romano, R Belfort Jr.. Survival analysis of conjuctival limbal grafts and amniotic membrane transplantation in eyes with total limbal stem cell deficiency. Am. J. Ophthalmol., 140 (2005), pp. 223-230. 
Shimmura and Tsubota, 2002. S Shimmura, K. Tsubota. Ocular surface reconstruction update. Curr. Opin. Ophthalmol., 13 (2002), pp. 213-219.

Soncini et al., 2007. M Soncini, E Vertua, L Gibelli, F Zorzi, M Denegri, A Albertini, GS Wengler, O. Parolini. Isolation and characterization of mesenchymal cells from human fetal membranes. J. Tissue Eng. Regen. Med., 1 (2007), pp. 296-305.

Steigman and Fauza, 2007. S.A. Steigman, D.O. Fauza. Isolation of mesenchymal stem cells from amniotic fluid and placenta. Curr. Protoc. Stem. Cell. Biol. (2007); Chapter 1, Unit 1E.2.

Steinert et al., 2007. AF Steinert, SC Ghivizzani, A Rethwilm, RS Tuan, CH Evans, U. Nöth. Major biological obstacles for persistent cell-based regeneration of articular cartilage. Arthritis Res. Ther., 9 (2007), p. 213.

Stenderup et al., 2003. K Stenderup, J Justesen, C Clausen, M. Kassem. Aging is associated with decreased maximal life span and accelerated senescence of bone marrow stromal cells. Bone, 33 (2003), pp. 919-926.

Takashima et al., 2004. S Takashima, H Ise, P Zhao, T Akaike, T. Nikaido. Human amniotic epithelial cells possses hepatocyte-like characteristics and functions. Cell Struct. Funct., 29 (2004), pp. 73-84.

Tamagawa et al., 2004. T Tamagawa, I Ishiwata, S. Saito. Establishment and characterization of a pluripotent stem cell line derived from human amniotic membranes and initiation of germ layers in vitro. Hum. Cell, 17 (2004), pp. $125-130$.

Tamagawa et al., 2007. T Tamagawa, S Oi, I Ishiwata, H Ishikawa, Y. Nakamura. Differentiation of mesenchymal cells derived from human amniotic membranes into hepatocyte-like cells in vitro. Hum. Cell, 20 (2007), pp. 7784.

Tamagawa et al., 2008. T. Tamagawa, I Ishiwata, H Ishikawa, Y. Nakamura. Induced in vitro differentiation of neural-like cells from human amnion-derived fibroblast-like cells. Hum. Cell, 21 (2008), pp. 38-45.

Tanaka et al., 1999. M Tanaka, Z Chen, S Bartunkova, N Yamasaki, S. Izumo. The cardiac homeobox gene Csx/Nkx2.5 lies genetically upstream of multiple genes essential for heart development. Development, 126 (1999), pp. 1269-1280.

Tejwani et al., 2007. S Tejwani, RS Kolari, VS Sangwan, GN. Rao. Role of amniotic membrane graft for ocular chemical and thermal injuries. Cornea, 26 (2007), pp. 21-26.

Toda et al., 2007. A Toda, M Okabe, T Yoshida, T. Nikaido. The potential of amniotic membrane/amnion-derived cells for regeneration of various tissues. J. Pharmacol. Sci., 105 (2007), pp. 215-228.

Tritz et al., 2010. J Tritz, R Rahouadi, N de Isla, N Charif, A Pinzano, D Mainard, D Bensoussan, P Netter, J-F Stoltz, N Benkirane -Jessel, C Huselstein. Designing a three-dimensional alginate hydrogel by spraying method for cartilage tissue engineering. Soft Matter, 6 (2010), pp. 5165-5174.

Tsai et al., 2007. MS Tsai, SM Hwang, KD Chen, YS Lee, LW Hsu, YJ Chang, CN Wang, HH Peng, YL Chang, AS Chao, SD Chang, KD Lee, TH Wang, HS Wang, YK. Soong. Functional network analysis on the transcriptomes of mesenchymal stem cells derived from amniotic fluid, amniotic membrane, cord blood, and bone marrow. Stem Cells, 25 (2007), pp. 2511-2523.

Uchida et al., 2000. S Uchida, Y Inanaga, M Kobayashi, S Hurukawa, M Araie, N. Sakuragawa. Neurotrophic function of conditioned medium from human amniotic epithelial cells. J. Neurosci. Res., 62 (2000), pp. 585-590.

Villaron et al., 2004. EM Villaron, J Almeida, N Lopez-Holgado, M Alcoceba, LI Sánchez-Abarca, FM SanchezGuijo, M Alberca, JA Pérez-Simon, JF San Miguel, MC Del Cañizo. Mesenchymal stem cells are present in peripheral blood and can engraft after allogenic haematopoietic stem cell transplantation. Haematologica, 89 (2004), pp. 1421-1427.

Wakitani et al., 1989. S Wakitani, T Kimura, A Hirooka, T Ochi, M Yoneda, N Yasui, H Owaki, K. Ono. Repair of rabbit articular surfaces with allograft chondrocytes embedded in collagen gel. J. Bone Joint Surg. Br., 71 (1989), pp. 74-80.

Wei et al., 2009. JP Wei, M Nawata, S Wakitani, K Kametani, M Ota, A Toda, I Konishi, S Ebara, T. Nikaido. Human amniotic mesenchymal cells differentiate into chondrocytes. Cloning Stem Cells, 11 (2009), pp. 19-25.

Wei et al., 2003. JP Wei, TS Zhang, S Kawa, T Aizawa, M Ota, T Akaike, K Kato, I Konishi, T. Nikaido. Human amnion-isolated cells normalize blood glucose in streptozotocin-induced diabetic mice. Cell Transplant., 12 (2003), pp. 545-552.

Wilshaw et al., 2006. SP Wilshaw, JN Kearney, J Fisher, E. Ingham. Production of an acellular amniotic membrane matrix for use in tissue engineering. Tissue Eng., 12 (2006), pp. 2117-2129.

Wolbank et al., 2007. S Wolbank, A Peterbauer, M Fahrner, S Hennerbichler, M van Griensven, G Stadler, H Redl, C Gabriel. Dose-dependent immunomodulatory effect of human stem cells from amniotic membrane: a comparison with human mesenchymal stem cells from adipose tissue. Tissue Eng., 13 (2007), pp. 1173-1183.

Wong et al., 2005. BJ Wong, N Pandhoh, MT Truong, S Diaz, K Chao, S Hou, D. Gardiner. Identification of chondrocyte proliferation following laser irradiation, thermal injury, and mechanical trauma. Lasers Surg. Med., 37 (2005), pp. 89-96.

Yanada et al., 2006. S Yanada, M Ochi, K Kojima, P Sharman, Y Yasunaga, E. Hiyama. Possibility of selection of chondrogenic progenitor cells by telomere length in FGF-2-expanded mesenchymal stromal cells. Cell Prolif., 39 (2006), pp. 575-584.

Yoo et al., 1998. JU Yoo, TS Barthel, K Nishimura, L Solchaga, AI Caplan, VM Goldberg, B. Johnstone. The chondrogenic potential of human bone-marrow-derived mesenchymal progenitor cells. J. Bone Joint Surg. Am., 80 (1998), pp. 1745-1757.

You et al., 2008. Q You, L Cai, J Zheng, X Tong, D Zhang, Y. Zhang. Isolation of human mesenchymal stem cells from third-trimester amniotic fluid. Int. J. Gynaecol. Obstet., 103 (2008), pp. 149-152.

Young et al., 2001. HE Young, TA Steele, RA Bray, J Hudson, JA Floyd, K Hawkins, K Thomas, T Austin, C Edwards, J Cuzzourt, M Duenzl, PA Lucas, AC Black Jr.. Human reserve pluripotent mesenchymal stem cells are 
present in the connective tissues of skeletal muscle and dermis derived from fetal, adult, and geriatric donors. Anat. Rec., 264 (2001), pp. 51-62.

Yuan et al., 2010. T Yuan, L Zhang, L Feng, H Fan, X. Zhang. Chondrogenic differentiation and immunological properties of mesenchymal stem cells in collagen type I hydrogel. Biotechnol. Prog. (2010) July 28 (Epub ahead of print).

Zhao et al., 2005. P Zhao, H Ise, M Hongo, M Ota, I Konishi, T. Nikaido. Human amniotic mesenchymal cells have some characteristics of cardiomyocytes. Transplantation, 79 (2005), pp. 528-535.

Zimmermann et al., 2003. S Zimmermann, M Voss, S Kaiser, U Kapp, CF Waller, UM. Martens. Lack of telomerase activity in human mesenchymal stem cells. Leukemia, 17 (2003), pp. 1146-1149.

Zuk et al., 2002. PA Zuk, M Zhu, P Ashjian, DA De Ugarte, JI Huang, H Mizuno, ZC Alfonso, JK Fraser, P Benhaim, MH. Hedrick. Human adipose tissue is a source of multipotent stem cells. Mol. Biol. Cell, 13 (2002), pp. 4279-4295.

Zuk et al., 2001. PA Zuk, M Zhu, H Mizuno, J Huang, JW Futrell, AJ Katz, P Benhaim, HP Lorenz, MH. Hedrik. Multilineage cells from human adipose tissue: implications for cell-based therapies. Tissue Eng., 7 (2001), pp. 211-228.

Zvaifler et al., 2000. NJ Zvaifler, L Marinova-Mutafchieva, G Adams, CJ Edwards, J Moss, JA Burger, RN. Maini. Mesenchymal precursor cells in the blood of normal individuals. Arthritis Res., 2 (2000), pp. 477-488. 